\title{
VERTICAL FARMING SEBAGAI UPAYA KONSERVASI EKOLOGI BUMI
}

\author{
Darren Ariel Yeremia ${ }^{1)}$, Nina Carina ${ }^{2)}$ \\ 1)Program Studi S1 Arsitektur,Fakultas Teknik, Universitas Tarumanagara, darrenariel@gmail.com \\ 2) Program Studi S1 Arsitektur,Fakultas Teknik, Universitas Tarumanagara, ninac@ft.untar.ac.id
}

Masuk: 04-07-2021, revisi: 13-08-2021, diterima untuk diterbitkan: 23-10-2021

\begin{abstract}
Abstrak
Makanan adalah kebutuhan pokok manusia. Manusia memiliki berbagai macam cara untuk terus menghasilkan makanan dengan jumlah yang semakin banyak dan kualitas yang bervariasi. Kegiatan untuk produksi makanan ini selalu memiliki koneksi yang erat dengan keadaan ekosistem dimana populasi manusia itu berada. Industri pertanian merupakan salah satu kontributor terbesar produksi makanan. Sebagai sumber utama bahan baku makanan manusia, kemajuan teknologi industri pertanian menjadi fokus utama riset pangan. Kemajuan ini banyak mempengaruhi ekologi. Penggunaan pestisida dan zat kimia dalam industri pertanian mengakibatkan polusi air bagi sungai dan danau di sekitar lahan pertanian. Pertanian konvensional membutuhkan area yang sangat luas untuk menopang kebutuhan pangan manusia. Dengan memanfaatkan ekosistem alami seperti hutan hujan dan jenis bio-sphere lainnya, rusaknya keadaan alam juga menghancurkan rantai makanan alami yang lambat laun akan mempengaruhi manusia itu sendiri. Pemanfaatan ruangruang vertikal kota dapat menjadi salah satu solusi alternatif dari industri makanan yang selalu harus bertumbuh. Konsep ini biasa disebut sebagai program "Vertical Farming". Upaya ini dapat menjadi solusi bagi manusia yang sekarang banyak tinggal di kota untuk memenuhi kebutuhannya tanpa harus merusak keadaan ekologi lebih jauh lagi. Tani Tumpuk Ragunan; Produksi Makanan dari Kota Untuk Kota merupakan upaya desain secara arsitektural untuk mengembalikan kegiatan produksi makanan ke dalam kota dengan memanfaatkan tenaga-tenaga terbarukan sebagai bentuk pendekatan melampaui ekologi.
\end{abstract}

Kata Kunci : Agrikultur; Melampaui Ekologi; Tani Tumpuk, Populasi; Vertical Farming

\begin{abstract}
Food has always been a staple need for humans. And humans always have so many ways to keep producing food in larger quantities and better qualities with a lot of variety. The activity of producing food always has a strong connection to the ecosystem condition of where the human population resided. One of the most contributing elements to food production for the human population is the agricultural industry. As one of the most contributor to human food production, technological advancement in the agricultural industry has always been the main topic of researches related to food. But recently these advancements have affected the ecology. For example, the use of pesticide and other chemicals becomes pollution for rivers and lakes around farms. Conventional agriculture requires a lot of area to sustain human food needs. These areas are taken from many natural ecologies like rainforests or other bio-spheres, the damages done to nature will affect the natural food chain and eventually affects humanity itself. The use of vertical spaces of human cities can be used as an alternative to the ever expanding needs of space for the food industry. This concept is called "Vertical Farming". this effort can be the solution for humans who now live mostly in cities to provide for their own, without damaging the ecology more. Ragunan Stack Farm : Producing Food From City for The City is an architectural effort to move food industry activities back to cities, using sustainable development approach and energies as an approach to go beyond ecology.
\end{abstract}

Keywords : Agriculture; Beyond Ecology; Consumption; Population; Stack Farming; Vertical Farming 


\section{PENDAHULUAN}

\section{Latar Belakang}

Makanan selalu menjadi salah satu subjek terpenting dalam sejarah kehidupan manusia dan seluruh makhluk hidup di bumi. sebagai sumber energi, makanan juga membentuk evolusi makhluk hidup, dan dalam kehidupan manusia, bahkan membentuk budaya dari sebuah peradaban.

Kota berawal dari sekumpulan tempat tinggal manusia dalam suatu tempat. Posisi dan letak kotakota awal ini menjadi pusat dari kegiatan sekumpulan manusia tersebut. kota menjadi tempat menyimpan makanan dan peralatan, lokasi kegiatan komersil, administrative dan lain-lain. Beberapa kota bahkan menjadi tempat dimana makanan diproduksi. Kota-kota ini dikelilingi dengan sawah-sawah. Sungai, danau atau laut untuk memancing ikan, atau tempat berburu. Dengan jumlah populasi yang semakin banyak dalam setiap kota, dan jumlah kota yang bertambah secara pesat. Makanan yang dibutuhkan semakin banyak, begitu pula lahan yang dibutuhkan untuk memproduksi makanan tersebut.

Sampai dengan abad ke-21, 38\% massa daratan di bumi digunakan untuk kegiatan agrikultur. 38\% luas lahan ini digunakan untuk memberi makan kota-kota yang mengambil 3\% dari massa daratan di bumi (Bailkey M., 2000). kegiatan agrikultur ini tidak hanya mempengaruhi ekologi dengan mengambil lahan. Setiap lahan yang diubah menjadi daerah pertanian juga menghancurkan ekosistem alami yang ada. Lambat laun keadaan ekologi besar yaitu bumi dapat berubah hanya untuk memproduksi makanan bagi manusia.

Urbanisasi mendorong kota untuk terus berkembang dan meluas. Pada tahun 1800 dimana 10\% populasi dunia tinggal di kota. Dan pada tahun 2010, PBB menyatakan 50\% populasi manusia di bumi tinggal di kota. Jumlah ini akan terus bertambah dengan meningkatnya pendapatan dan minat industri agrikultur yang semakin menurun. Sedangkan kebutuhan untuk makanan tidak akan menurun. Namun belakangan ini muncul kegiatan-kegiatan baru seperti urban farming yang memiliki tujuan untuk memproduksi makanan dari kota untuk kota. Implementasi ide-ide dan program kegiatan tersebut dapat menyelamatkan bumi dari kerusakan ekologi yang dikarenakan kebutuhan makanan oleh kota.

\section{Rumusan Permasalahan}

Dari latar belakang diatas, rumusan permasalahan yang dapat ditarik adalah bagaimana arsitektur dapat menyatukan ekologi buatan manusia yaitu kota dan sebuah pertanian, dengan ekologi alami. Proyek ini dirancang untuk menjadi sebuah contoh desain bagaimana sebuah pertanian dapat masuk ke dalam kota. Bagaimana sebuah urban vertical farm dapat menggunakan energi terbarukan dan memanfaatkan ruang vertikal kota. Sehingga pertanian vertikal ini tetap dapat memproduksi makanan tanpa merugikan ekologi alami. Dan bagaimana sebuah pertanian vertikal dapat mengakomodasi kegiatan edukasi publik. Mengajarkan hubungan antara produksi makanan dengan ekologi dan bagaimana masyarakat kota dapat membantu mengurangi dampak negatif dari industry agrikultur konvensional.

\section{Tujuan}

Sebuah pertanian vertikal dengan prinsip pertanian organik dapat menjadi sebuah jawaban. Menggunakan ruang-ruang vertikal kota untuk meminimalisir perluasan lahan sebagai area-area untuk menumbuhkan makanan. Ragunan yang menjadi tempat kebun binatang terbesar di Indonesia yang dibangun dengan konsep hutan hujan dapat menjadi lokasi yang ideal untuk sebuah lahan pertanian di dalam kota. Sebuah upaya menggabungkan 2 ekologi yang berbeda. Pertanian kota organik yang meminimalisir dampak negatif industry agrikultur juga dapat membentuk habitat baru untuk makhluk hidup luar kota yang lebih kecil seperti burung dan serangga. 
Ragunan juga merupakan lokasi kebun binatang terbesar di Indonesia, yang di desain dengan konsep hutan hujan. Gradasi antara ekosistem alami dengan ekosistem kota buatan manusia di Ragunan dapat menjadi titik mulainya aplikasi konsep sebuah kota yang dapat memproduksi makanannya sendiri dan berdamai dengan ekologi.

\section{KAJIAN LITERATUR}

\section{Beyond Ecology}

Sebuah ekologi membutuhkan aspek biotik atau makhluk hidup. Makhluk hidup di dalam sebuah sistem ekologi menjadi katalis terjadinya perkembangan dari sistem ekologi tersebut. menjadi semakin luas dan semakin variatif (Capra, 1996). Variasi makhluk hidup juga mempengaruhi aspekaspek abiotik dari sistem ekologi tersebut, seperti keadaan geografis sampai dengan tingkat oksigen area tersebut. setiap aspek biotik dan abiotik, yang sudah ada dan yang baru ada, menjadi bergantung dengan satu sama lain. Hilangnya satu aspek tersebut mempengaruhi satu sistem ekologi secara keseluruhan. Sebagai contoh, jika satu jenis tanaman punah dari sebuah ekologi, serangga atau hewan herbivor yang mengkonsumsi tanaman tersebut ikut terpengaruh dan memiliki kemungkinan ikut punah. Begitu pula hewan karnivor yang harusnya mengkonsumsi serangga atau hewan herbivor tersebut. hilangnya makhluk hidup dari tempat tersebut lambat laun mengubah keadaan tempat tersebut yang kedepannya tidak dapat menyokong lagi makhluk hidup. perubahan aspek abiotik dalam sebuah ekologi juga dapat merusak kehidupan makhluk biotik di sana. Ekologi adalah sebuah sistem kompleks yang terbentuk dari hubungan antara aspek-aspek biotik di sebuah tempat dengan aspek-aspek abiotic di tempat tersebut (Dan L. Perman, 2004). dan sistem ini terbentuk secara natural di bumi, jauh sejak manusia pertama di bumi hidup.

Beyond Ecology adalah sebuah prinsip untuk melampaui ekologi natural yang memang sudah ada di bumi, dan menyatukannya dengan sistem ekologi buatan manusia lewat teknologi yang lebih maju. Praktek prinsip ini sebenarnya sudah banyak dimplementasikan. Sebagai contoh, sebuah perusahaan agrikultur kota Bernama AeroFarms, yang berlokasi di New Jersey, Amerika Serikat menggunakan kecerdasan buatan untuk mengontrol laju air untuk tanaman yang ditumbuhkan di dalam instalasinya.

Beyond Ecology mendorong dan menyatukan kedua sistem kompleks menjadi satu untuk hidup menguntungkan satu sama lain. Implementasi teknologi mungkin dapat membantu bagaimana kemajuan umat manusia untuk tidak hanya mengandalkan ekologi, namun memperbaiki ekologi natural lewat pengembangan ekologi buatan yang lebih ramah ekologi alami.

Parameter untuk melampaui ekologi adalah sebagai berikut :

- Konteks: Kemampuan desain untuk merespon konteks tapak. Bagaimana desain akan merespon dan bagaimana desain akan mempengaruhi keadaan ekologi di dalam tapak dan sekitarnya.

- Energi dan Emisi: Proyeksi pengunaan energi dan emisi yang dihasilkan oleh desain. Emisi karbon dioksida menjadi salah satu masalah terbesar oleh pertanian konvensional. Energi yang digunakan juga Sebagian besar diupayakan berasal dari sumber yang terbarukan seperti angin dan matahari

- Adaptasi: Kemampuan bangunan untuk beradaptasi dengan isu dan masalah yang mungkin muncul pada tapak dan daerah sekitarnya. Bangunan dapat bertahan dan dapat tetap digunakan sesuai fungsinya dengan tambahan sesuai dengan adaptasi yang diperlukan.

- Teknologi Baru: Aplikasi dan implementasi teknologi baru ke dalam desain. Dan bagaimana implementasi-implementasi tersebut dapat memudahkan pengguna dalam beraktivitas di dalam bangunan.

- Sustainable Digital: Kolaborasi bangunan dengan keadaan tapak dan bagaimana bangunan dan area tapak mempengaruhi satu sama lain dalam jangka panjang 
- Ketahanan: Kekuatan dan ketahanan bangunan dari segi struktur dan fungsi. Seberapa lama bangunan dapat digunakan sesuai fungsinya. Sampai kapan fungsi tersebut masih berhubungan dengan konsep dan isu yang ingin dijawab oleh desain.

Keenam poin diatas dijadikan parameter untuk menentukan apakah sebuah bangunan mampu melampaui ekologi atau tidak. Keenam poin tersebut dapat diaplikasikan ke berbagai bangunan dengan berbagai fungsi dengan bermacam-macam latar belakang dan isu. Dan parameterparameter ini membantu meleburkan batas antara ekologi alami dan ekologi buatan menuju melampaui ekologi. Dimana ekologi alami tidak lagi perlu dirugikan.

\section{Ekspansi Kota dan Masalahnya}

Beberapa masalah kota modern di abad ke-21 antara lain :

- Tidak dapat menghasilkan makanannya sendiri. Sedangkan tempat untuk memproduksi makanannya menghilangkan ekosistem yang sudah ada.

- Penghasil terbesar polusi air dan udara

- Ekspansi kota terus mengambil alih area "alam liar"

Secara perlahan, masalah-masalah ini yang kedepannya juga akan membunuh manusia (Dan L. Perman, 2004). Kota yang tadinya menjadi tempat berkumpul dan membentuk sistem kemasyarakatan, juga menjadi kemungkinan pembunuh ekologi bumi.

Masalah-masalah ini juga baru dapat terdeteksi dan baru dapat diatasi dengan teknologi-teknologi yang baru muncul. Seperti penggunaan turbin angin atau solar panel. Namun teknologi-teknologi tersebut juga memiliki masalah. Turbin angin dan solar panel harganya cukup mahal, dan membutuhkan area yang luas agar dapat bekerja secara efektif. Aplikasi solar panel per rumah juga tidak dapat dilakukan secara efektif dan massal karena tidak semua orang mampu membeli dan merawatnya. Solar panel juga masih memerlukan bantuan dari penyuplai tenaga listrik konvensional. Produksi makanan untuk kota juga menjadi masalah serius. $26 \%$ dari total luas daratan di bumi sudah digunakan untuk kegiatan agrikultur dan beternak. Namun berdasarkan WHO, sampai hari ini masih ada 132.000 .000 manusia yang belum dapat makan setiap hari. Dan $40 \%$ dari total populasi dunia belum bisa menikmati daging sebagai bagian dari asupan gizi per hari.

Perluasan area produksi makanan akan memberikan dampak negatif untuk bumi. Meskipun sawah dan peternakan merupakan area dengan udara dan keadaan alam yang bersih, mereka memiliki variasi kehidupan yang minim. Hilangnya variasi makhluk hidup akan memutus rantai makanan dalam sebuah ekologi (Jorgenssen, 2002). Semakin banyak pusat produksi makanan juga membutuhkan suplai bahan bakar yang tidak tergantikan seperti bensin dan batu bara.

\section{Kelemahan Pertanian Konvensional}

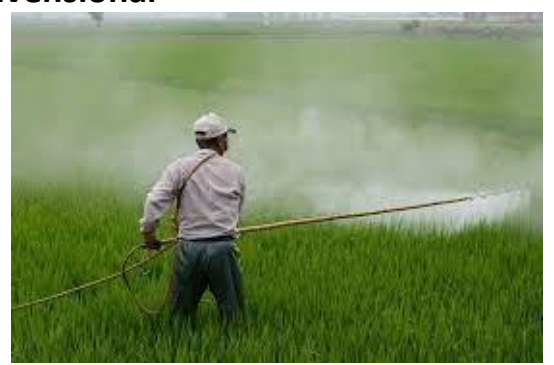

Gambar 1. Penggunaan Pestisida Pada Pertanian Konvensional

Sumber : www.google.com, 2017

Beberapa aktivitas produksi makanan manusia menghilangkan kepentingan aspek makhluk biotik dan aspek abiotik lain di muka bumi, beberapa contohnya antara lain : 
- Penggunaan pestisida pada tanaman mengurangi keberagaman makhluk hidup pada ekosistem hutan atau sawah

- Emisi Co2 dari kegiatan agrikultur menjadi salah satu penyumbang terbesar penyebab masalah efek rumah kaca

- Limbah air dari sawah dan pertanian mengandung unsur-unsur atau zat kimia berbahaya yang masuk ke sungai-sungai dan merusak ekologi karena meracuni makhluk hidup. hal ini mengakibatkan Terjadinya penyusutan ukuran makhluk hidup air tawar dan asin sebanyak 50\% dari tahun 1950-2020.

Beberapa kegiatan ini merupakan contoh kegiatan produksi manusia yang merusak keseimbangan ekologi. Sifat konsumerisme manusia terutama di abad ke-21 me-nomorduakan keseimbangan ekologi bumi (Devall, 1985). Melihat cara ekologi bekerja, sifat yang merusak ini lambat laun akan mempengaruhi manusia secara langsung. Sebagai contoh, hasil produksi pertanian konvensional sekarang banyak mengandung pestisida bahkan ketika sudah diperjualbelikan. Kandungan nutrisi di dalam produksi tersebut mengalami penurunan selama 10 tahun terakhir. Namun manusia tetap membutuhkan energi sehingga tidak mungkin menghilangkan kegiatan produksi makanan.

\section{Pertanian Organik}

Pertanian organik adalah sebuah sistem praktik agrikultur yang mulai dipraktikkan sejak awal abad ke-20 (Paull, 2019). Praktik pertanian organik berpusat pada mengurangi dampak negatif terhadap ekologi dan kesehatan manusia yang diakibatkan pertanian konvensional. Contoh aplikasi praktik tersebut antara lain penggunaan pestisida alami seperti pyrethrin atau bahkan menggunakan musuh alami dari hama tanaman. Praktik sistem ini sekarang banyak diatur dan diregulasi di berbagai negara di dunia, karena sistem ini memproduksi 1.5\% hasil panen di dunia per 2019 (FIBL \& FOAM, 2020). 6 poin yang difokuskan dari pertanian organik adalah :

- Sustainability: Kemampuan dari pertanian organic untuk menggunakan sumber energi terbarukan untuk mengurangi emisi dari kegiatan industri agrikultur. dan mengorganisasi pembuangan juga limbah dari industri agrikultur untuk mengurangi dampak negative terhadap ekosistem.

- Keterbukaan: Transparansi dari proses kegiatan industri pertanian organik. Dari proses pemilihan bibit, penanaman, perawatan dan panen. Keterbukaan memastikan kontrol yang lebih mudah untuk memastikan kegiatan industri dilakukan dengan peraturan dan regulasi yang berlaku.

- Kemandirian: Proses kegiatan industri mampu menggunakan fasilitas dan sumber daya yang ada tanpa bantuan signifikan dari faktor luar. Contohnya antara lain memanfaatkan air hujan sebagai sumber utama pengairan dan menggunakan panel surya sebagai sumber utama energi listrik.

- Kesehatan: Industri agrikultur organic tidak hanya memastikan kesehatan dari produksi panen. Tapi kesehatan pekerja dan komunitas di sekitar lokasi pertanian sampai dengan keadaan kesehatan pengkonsumsi produksi panen. Sebagai contoh, agrikultur organik tidak menggunakan pestisida kimia yang dapat menjadi racun jika dikonsumsi.

- Keamanan Stok Pangan: Dengan jumlah luas total lahan pertanian organic mencapai 73.000.000 hektar, praktik sistem agrikultur organik berusaha menyediakan dan menggantikan agrikultur konvensional sebagai sumber utama makanan sehat.

- Keamanan Kesehatan Pangan: Doktrin utama dari sistem agrikultur organik adalah memastikan hasil panen yang sehat ketika dalam proses produksi dan dalam proses panen. Kesehatan tanaman juga perlu diperhatikan agar tidak menimbulkan efek pada ekosistem area agrikultur. Sebagai contoh, penanaman tanaman yang terlalu terburu-buru tanpa membiarkan lahan tanam untuk beristirahat dapat merusak keadaan lahan.

6 poin diatas menjadi tuntunan untuk praktek agrikultur organik secara umum. Keenam poin ini juga sudah diaplikasikan di Indonesia sebagai pembentuk regulasi praktek agrikultur organik 


\section{Urban Farming}

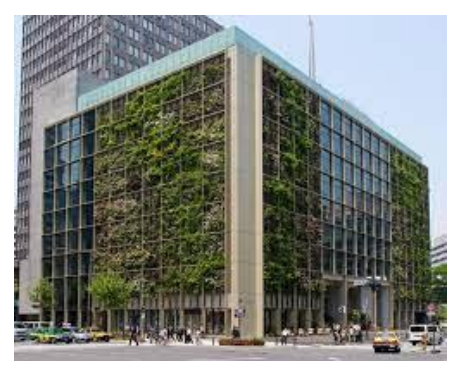

Gambar 2. Pasona Office, Tokyo. Sebuah Pertanian Kota

Sumber : www.archdaily.com, 2013

Praktek urban farming atau pertanian kota adalah praktik menanam, menumbuhkan, memanen dan mendistribusikan hasil panen di dalam atau di sekitar area kota (Bailkey M., 2000). Praktik ini digalakkan dewasa ini karena memiliki dampak yang cukup signifikan untuk merevolusi industri agrikultur konvensional. Pada awalnya praktik ini dilakukan dalam skala komunitas dengan tujuan :

- Membantu memproduksi makanan dan memberikan kesempatan ekonomi

- Penghijauan membantu menyehatkan komunitas pelaku pertanian kota

- Mengedukasi komunitas mengenai peran masyarakat sipil dalam kegiatan produksi makanan Praktek pertanian kota sebenarnya sudah dilakukan sejak abad ke-1 sebelum masehi di Persia, dimana setiap rumah di kota-kota kerajaan Persia diberi jarak dengan jalan sebagai area tanam. Presiden Amerika Serikat pada masa perang dunia pertama, Woodrow Wilson, menyuarakan agar setiap penduduk Amerika Serikat menanam makanannya sendiri di rumah masing-masing (Andre, 1999). Praktik ini banyak digalakkan untuk mencapai kemandirian pangan dan pemanfaatan ruangruang kosong yang terbentuk di kota-kota. Ruang-ruang yang dapat digunakan untuk menumbuhkan dan memproduksi makanan. Sampai dengan hari ini, 1/3 dari massa lahan bumi sudah digunakan untuk kegiatan agrikultur dan peternakan. $70-80 \%$ hasil produksi agrikultur pun digunakan untuk memberi makan ternak (Andre, 1999). Sementara ruang-ruang vertikal kota berdiri kosong tanpa fungsi. Ruang-ruang ini dapat dimanfaatkan untuk kegiatan agrikultur.

\section{METODE}

\section{Metode Penelitian}

Metode yang digunakan adalah metode kualitatif. Data yang digunakan berasal dari buku dan jurnal. Dianalisa dengan teori arsitektur dan ilmu agrikultural untuk merancang ruang-ruang tanam agrikultur di ruang-ruang vertikal kota. Metode ini digunakan untuk memahami isu dan bagaimana penulis dapat menyikapi isu tersebut. Penelitian kualitatif digunakan untuk memperhatikan fenomena, aspek objektif, kebutuhan dan hal-hal lain yang diperlukan untuk membangun sebuah pertanian vertikal.

Dengan memperhatikan dan menelaah informasi dan data yang telah dikumpulkan. program arsitektur dapat terbentuk.

\section{Metode Perancangan}

Pemilihan metode perancangan mengacu pada standar-standar dan ketentuan-ketentuan untuk sebuah pertanian organik. Konsep pertanian organic merupakan konsep produksi makanan yang sangat meminimalisir dampak negatif agrikultur terhadap ekologi. 6 poin yang menjadi fokus dalam metode perancangan adalah sebagai berikut :

- Energi: Sumber utama energi bangunan berasal dari sumber yang terbarukan, seperti tenaga matahari atau angin. Hal ini membantu bangunan mengurangi emisi Co2 yang dihasilkan dari bahan bakar konvensional dan mengedepankan poin kemandirian dari prinsip pertanian organik. 
- Air: Penggunaan air yang lebih terkontrol dalam industry agrikultur. berupa sistem kontrol dan pengawasan penggunaan air yang terukur. penggunaan sistem daur ulang air yang dapat digunakan kembali dalam kegiatan produksi. Dan meminimalisir air buangan ke dalam riol kota.

- Kesehatan: Kesehatan produksi panen dan kesehatan pekerja. Area produksi panen harus dibangun sesuai dengan standar kesehatan industry agrikultur pada umumnya. Didukung dengan tidak adanya penggunaan pestisida pada kegiatan produksi panen. Pengadaan fasilitas untuk pekerja produksi seperti area beristirahat, area penyimpanan barang yang terpisah dan terisolasi sehingga meminimalisir terjadinya kontaminasi pada area produksi dan fasilitas pendukung lainnya.

- Pembuangan: Penggunaan bio-waste sebagai elemen pendukung kegiatan produksi seperti kompos. Selain itu manajemen pembuangan bangunan juga didesain agar tidak mengkontaminasi area-area yang berhubungan dengan kegiatan produksi.

- Manajemen: Perawatan tanaman dilakukan sesuai dengan protokol dan ketentuan prosedur pertanian organik. Selain itu kegiatan produksi panen harus bersifat transparan untuk memudahkan prosedur kontrol apakah kegiatan produksi sudah sesuai dengan ketentuan yang berlaku.

- Enviormental: Desain harus meminimalisir pengeluaran emisi Co2 dan meminimalisir kemungkinan kontaminasi akibat limbah yang dihasilkan kegiatan produksi.

\section{DISKUSI DAN HASIL}

Program

Untuk memanfaatkan ruang-ruang vertikal di kota sebagai area tanam dibutuhkan ruang bebas vertikal untuk mewadahi kegiatan agrikultur. ruang-ruang vertikal ini membentuk kesan sawahsawah yang ditumpuk. Sebagai contoh, area seluas $1.000 \mathrm{~m}^{2}$, didukung dengan struktur yang sesuai dengan kaidah arsitektural yang berlaku dapat membangun 5 tingkat ruang tanam seluas $750 \mathrm{~m} 2$.

Area seluas $1.000 \mathrm{~m} 2$ dapat digunakan untuk menumbuhkan tanaman seluas $3.500 \mathrm{~m} 2$. Kegiatan industry agrikultur tidak lepas dari kebutuhan untuk memproses hasil panen. Hasil panen ini perlu diproses di lokasi untuk memastikan kesegaran hasil panen ketika didistribusikan dalam waktu dekat. Proses dan distribusi dalam waktu yang singkat memastikan ketersidiaan pangan yang segar dan sehat dari hari ke hari.

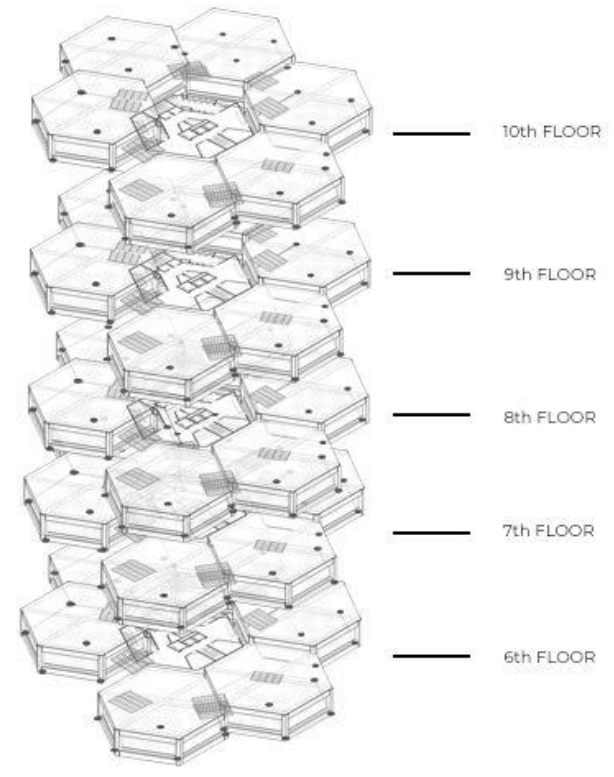

Gambar 3. Desain Sawah Tumpuk Membentuk Spiral Sumber : Penulis, 2021 
Area tanam berupa modul-modul hexagonal seluas $260 \mathrm{~m}^{2}$. Modul-modul ini disatukan dengan satu core. Per lantai terdapat 6 modul sebagai fasilitas tanam, dan dibagi menjadi 5 lantai area tanam dalam satu menara. Dan di dalam desain terdapat 2 menara. Setiap modul ini disambungkan dan memiliki perbedaan ketinggian, sehingga setiap lantai terhubung dengan modul-modul lantai dibawahnya dengan ramp. Hal ini memudahkan transportasi dan pembagian area tanam per awal waktu tanam.

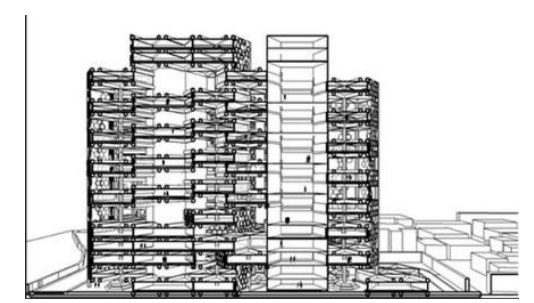

Gambar 4. Hubungan Antar Modul Lewat Potongan Perspektif Sumber : Penulis, 2021

\section{Analisa Tapak}

Untuk dapat membaca konteks tapak, dibutuhkannya analisa tapak. Mulai dari memperhatikan tapak dan sekitarnya untuk mendapatkan nilai positif dan negatif pada tapak. Analisa akan memberikan landasan mendesain dan menyikapi dalam bentuk sebuah rancangan. Sehingga rancangan dirasa tepat sasaran dan guna.

- Aksesibilitas dan Area Tapak

Tapak berada di Kecamatan Ragunan. Tepatnya berada di Jl. Saco Ragunan, yang berada tepat di samping barat Kandang Gajah Ragunan. Tapak dapat dicapai lewat Jl. KKO Raya Cilandak.

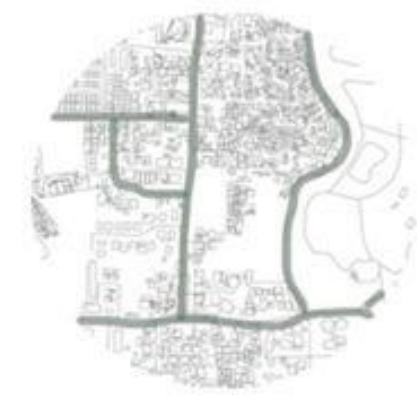

Gambar 5.. Aksesibilitas Tapak

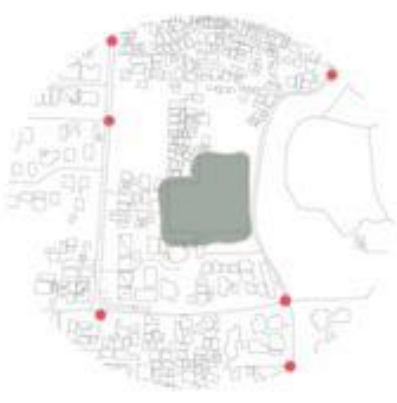

Gambar 6.Titik Pemberhentian Bus

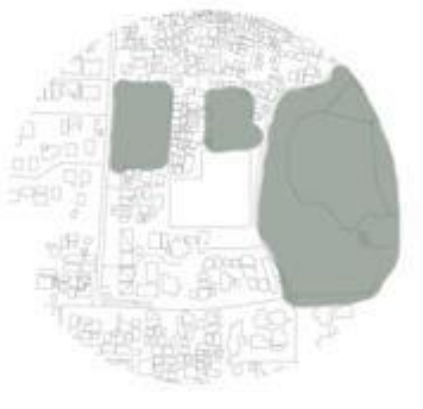

Gambar 7. Area Hijau di Sekitar Tapak

Jalan ini juga dilalui Transjakarta jalur 6N (Ragunan-Blok M). dan jalan Saco Ragunan mengarah ke halte Transjakarta Ragunan. Tapak ini menjadi salah satu pemberhentian bis di trotoar. Tapak eksisting dikelilingi area hijau. Area-area hijau ini berdasarkan peraturan zonasi memiliki fungsi tata kota yang nantinya akan dijadikan perumahan dengan ketinggan bangunan rendah. Namun sampai dengan saat ini, daerah-daerah ini masih ditumbuhi pepohonan lebat seperti hutan kota.

- Zonasi

Tapak dikelilingi perumahan-perumahan dengan ketinggian rendah namun dengan kepadatan tinggi. Perumahan-perumahan ini didominasi perumahan militer TNI AL. dan beberapa komplek perumahan elit. 


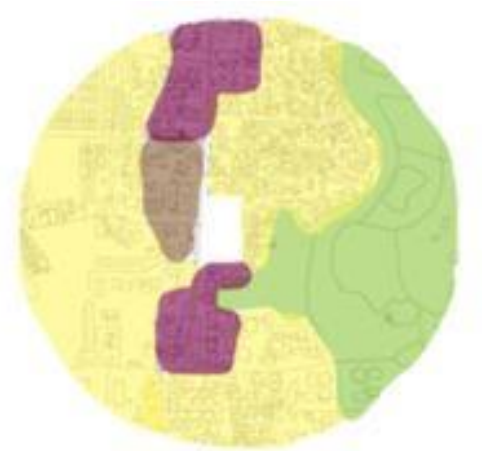

Gambar 8. Zonasi di Sekitar Tapak Sumber : Penulis, 2021

- Pedestrian

Jalanan-jalanan termasuk jalan Saco Ragunan masih dilengkapi dengan trotoar untuk pejalan kaki. ini memungkinkan pengguna bangunan yang menggunakan bis transjakarta yang mungkin berhenti cukup jauh dari lokasi untuk mencapai tapak dengan berjalan kaki.

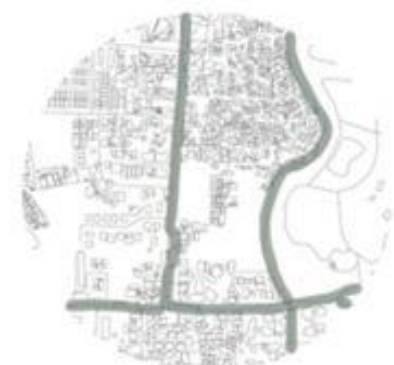

Gambar 9. Jalan yang Dilalui Trotoar di Daerah Ragunan

Sumber : Penulis, 2021

\section{Gubahan Massa}

Tapak dengan luas $12.780 \mathrm{~m}^{2}$ memiliki Koefisien Dasar Bangunan (KDB) 35\%, Koefisien Luas Bangunan (KLB) 3.5x, Koefisien Dasar Hijau (KDH) 45\%, dan Ketinggian Bangunan (KB) 24 Lantai. Tapak ini menghadap ke timur dengan dan berbatasan langsung dengan Jl. Saco Ragunan.

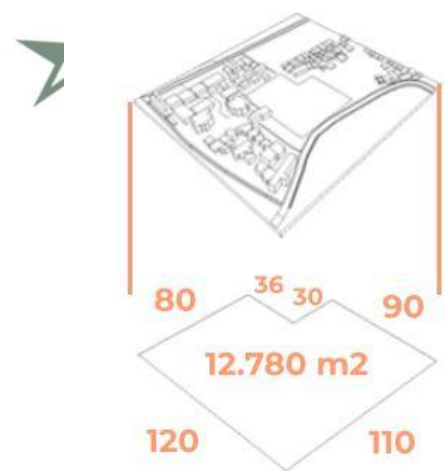

Gambar 10. Bentuk dan Dimensi Tapak Sumber : Penulis, 2021

Zona di dalam tapak dibagi menjadi 5 bagian secara horizontal. Memastikan area publik dan area parkir memanfaatkan kelebihan tapak yang meyambung dengan Jl. Saco Ragunan. Area masuk untuk pejalan kaki juga disambung dengan trotoar. Zonasi tapak dibentuk menjadi modul-modul hexagon sebagai bentuk dasar bangunan. 


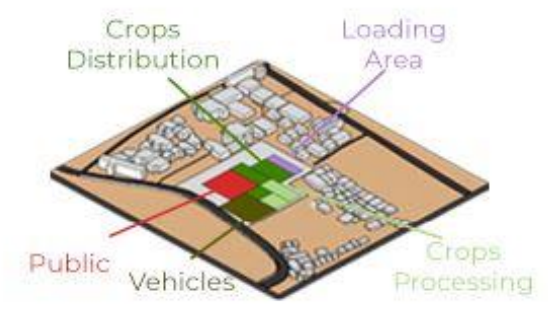

Gambar 11. Pembagian Tapak Dengan Zonasi Horizontal

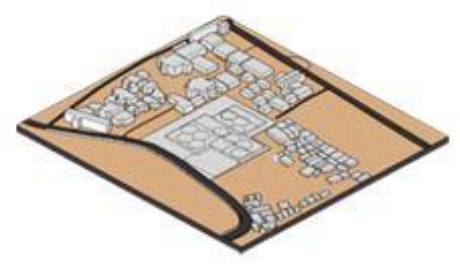

Gambar 12. Implementasi Bentuk Hexagon Dalam Tapak

Pembagian zoning selanjutnya dilakukan secara vertikal. Dimulai dengan pengadaan ruang publik seperti restoran dan area eksibihisi hasil produk panen. Lantai 2 selanjutnya berfungsi sebagai area semi-publik yang difungsikan sebagai kelas-kelas dan area pelatihan tenaga kerja atau kelompok masyarakat yang bersedia mengikuti pelatihan sebagai bentuk edukasi terhadap masyarakat umum. Lantai 3 menjadi area privat untuk pekerja dan karyawan pertanian vertikal. Lantai ini digunakan untuk area pra-tanam, dan bibit-bibit muda ini selanjutnya akan diantar ke area-area tanam diatasnya sesuai dengan zona tanaman masing-masing.
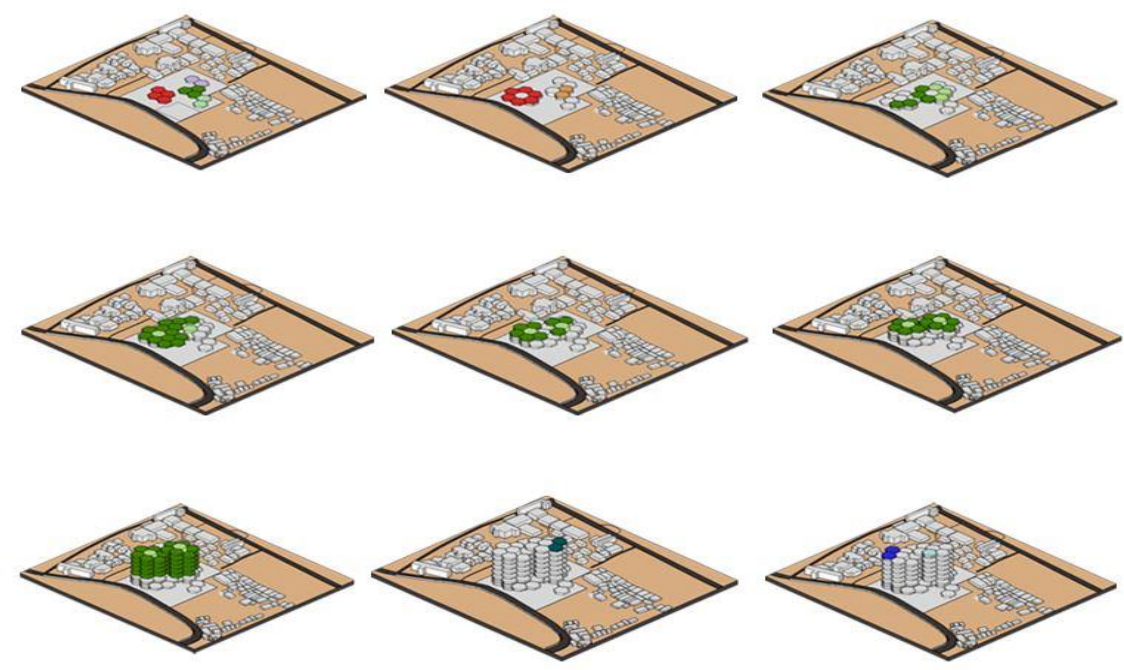

Gambar 13. Proses Pembentukkan Massa

Sumber : Penulis, 2021

Lantai 4 dan 5 dialokasikan untuk kegiatan tanam padi. Lantai 6 untuk bayam, lantai 7 untuk Bok Choy dan Cabai. Lantai 8 untuk wortel, lantai 9 untuk kacang Panjang dan bawang Bombay dan area tanam terakhir ada di lantai 10 untuk tomat. Pembagian ini berlaku untuk kedua Menara di dalam bangunan. Dilanjutkan dengan lantai 11 yang digunakan sebagai area kontrol suhu dan matahari untuk area tanam di bawahnya. Dan modul-modul hexagon terakhir di lantai 12 digunakan sebagai kantor manajemen yang bersifat diluar produksi dan kegiatan menanam. 


\section{Fasad Bangunan}

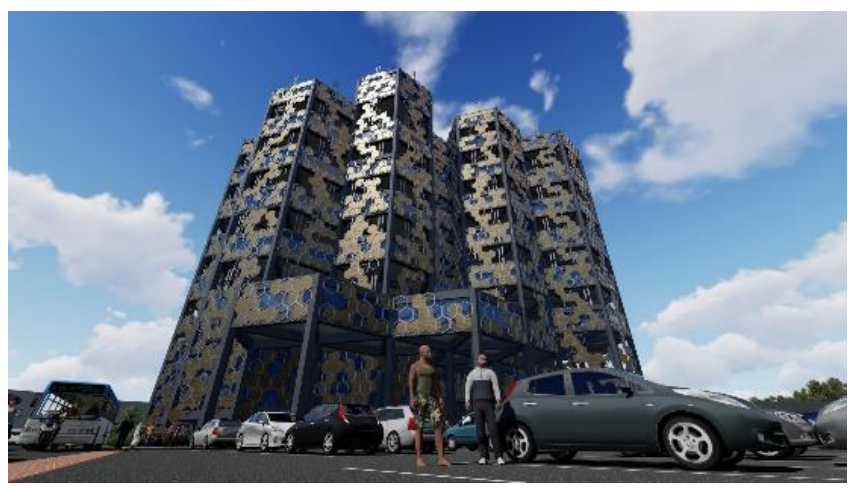

Gambar 14. Proses Pembentukkan Massa

Sumber : Penulis, 2021

Fasad adalah muka dari bangunan. Sebuah representasi guna dan citra. Eksperimen untuk mengangkat guna dan citra bangunan pada fasad merupakan sebuah tantangan. Dalam desain ini, fasad dibentuk dari bentuk dasar bangunan yang didesain sedemikian rupa.

Hexagon dipilih menjadi bentuk dasar bangunan karena sifatnya yang unik membentuk ruang secara maksimal dengan keliling kulit lebih sedikit. Hexagon juga dipilih menjadi bentuk fasad untuk menggambarkan kelebihan bentuk hexagon. Fasad yang dibentuk dari berbagai hexagon juga merepresentasikan sebuah sarang. Sebagaimana sarang lebah berfungsi sebagai rumah sebuah koloni lebah, termasuk tempat lebah menyimpan makanan. Tani Tumpuk Ragunan menjadi sarang yang mampu menghasilkan makanannya sendiri untuk daerah di sekitarnya.

Material yang digunakan terdiri dari 2 material dasar. pertama adalah hexagon yang dibuat dari bungkus-bungkus beton hampa. Didukung dengan hexagon-hexagon yang dibuat dari besi-besi baja hollow dan baja penuh. Hanya Sebagian kecil hexagon yang dibuat dari baja penuh berfungsi sebagai struktur untuk hexagon-hexagon lain yang terbuat dari baja ringan.

\section{KESIMPULAN DAN SARAN}

\section{Kesimpulan}

Makanan akan selalu menjadi kebutuhan pokok manusia. Ekspansi kota akan terus terjadi selama jumlah populasi manusia masih bertambah dan industri makanan akan selalu memerlukan solusisolusi baru untuk menghasilkan kuantitas makanan terbanyak dengan kualitas terbaik. Industry agrikultur yang juga akan selalu menjadi penghasil bahan baku untuk produksi makanan. Namun tidak selamanya industry agrikultur harus dilakukan dengan cara konvensional. Cara yang memberi dampak negatif terhadap ekologi.

Ruang-ruang vertikal kota dapat dapat digunakan untuk memproduksi makanan manusia. Mayoritas populasi manusia yang hidup di kota tidak lagi perlu merugikan mahkluk hidup yang tidak dapat tinggal di ekosistem kota. Pembangunan sebuah pertanian vertikal dapat menghasilkan jumlah yang lebih banyak dibanding luas yang digunakan pertanian vertikal tersebut. di waktu yang sama memberi kesempatan untuk ekosistem selain kota untuk tumbuh dan menyembuhkan dirinya sendiri.

Manusia sebagai makhluk yang dikatakan makhluk paling mulia tidak hanya memiliki hak terbanyak, tetapi tanggung jawab terberat. Untuk bertahan hidup dan menjaga kelangsungan tempat ia tinggal yaitu bumi. aristektur dan teknologi manusia dapat memudahkan manusia untuk melakukan keduanya. Kombinasi integrasi ruang-ruang dan desain bangunan dengan sistem kontrol terpusat dapat membantu sebuah bangunan pertanian vertikal untuk menghemat air. Sentral kontrol cahaya 
juga dapat membantu mengatur penggunaan listrik yang berfungsi sebagai matahari buatan. Tani Tumpuk Ragunan tidak bertujuan untuk sepenuhnya menjadi solusi terbaik alternatif produksi makanan yang lebih ramah lingkungan. Tetapi menjadi katalis untuk kota-kota dan daerah lain untuk menjadi lebih mandiri dalam sektor pangan demi ekologi luar kota yang lebih baik. Dan pada akhirnya setiap kota dapat mendorong dirinya sendiri melampaui ekologi.

\section{Saran}

Pemikiran dan hasil karya tugas akhir penulis ini masih jauh dari kata sempurna. Karya aristektur merupakan hasil dari ide. Dalam aristektur, tidak ada karya yang sempurna melainkan tepat. Ketepatan dalam berarsitektur memberikan ruang untuk adanya penyempurnaan. Untuk itu, penulis sangat terbuka akan saran dan masukan dari pembaca.

\section{REFERENSI}

Andre, V. (1999). Continuous Productive Urban Landscapes : Designing Urban Agriculture for Sustainable Cities. Oxford: Oxford Architectural Press.

Bailkey M., J. N. (2000). From Brownfields to Greenfields: Producing Food in North American Cities. Chicago: CSFC.

Capra, F. (1996). The Web of Life. London: Doubleday.

Dan L. Perman, J. C. (2004). Practical Ecology. London: Island Press.

Devall, B. (1985). Deep Ecology. Salt Lake City: Gibbs M. Smith.

FIBL \& FOAM. (2020). The World of Organic Architecture. 1.

Jorgenssen, S. (2002). Ecology and Enviorment (Vol. 3). Copenhagen: Springer-Science+BusinessMedia,B.V.

Paull, J. (2019). Organic Agriculture in Australia Attaining the Global Majority (51\%). American Insititute of Science (Journal of Enviorment Protection and Sustainable Development) 